\title{
The Reality of Educational Supervisors 'Practices for Supervisory Activities from the Point of View of the Public Schools Principals in Aqaba City- Jordan
}

\author{
Elham. N. Abu Hamde ${ }^{1}$ \\ ${ }^{1}$ Ministry of Education, Aqaba, Jordan \\ Correspondence: Elham N. Abu Hamde, Ministry of Education, Jordan. E-mail: info.aqaba@yahoo.com
}

Received: January 20, 2019

Accepted: January 26, 2019

Online Published: February 26, 2019

doi:10.5539/mas.v13n3p46

URL: https://doi.org/10.5539/mas.v13n3p46

\begin{abstract}
The study aimed at defining the reality of the supervisory activities for the educational supervisors from the point of view of the public schools principals in Aqaba city - Jordan. To achieve the study purposes the researcher used the descriptive methodology survey due to its appropriateness for the purposes of the study. The study instrument was built and it contained four domains and was applied on the study sample which consisted of (22) principal(male \&Female).The study results indicated that the reality of the educational supervisors practices for supervisory activities from the point of view of the public schools principals obtained an overall arithmetic mean of (3.80) with a high degree. However, on the secondary areas level the human relationships was ranked first with an arithmetic mean of (4.11) which was very high; in the second rank came the field of curriculum and text books with arithmetic mean of(3.98) which was high also; the third rank came the domain of learning and teaching with an arithmetic mean of (3.75) which was also high and in the last rank came the domain of school administration with an arithmetic mean of (3.5) which was medium.

The results of the study indicated that there are no differences between the means of the educational supervisors' practices for supervisory activities in terms of (sex, qualifications, management experience years). In the light of the study results a number of recommendations were proposed.
\end{abstract}

Keywords: reality, practices, educational supervisors, supervisory activities, School principals, Aqaba, Jordan

\section{Introduction}

Educational process areas since it is an integrated and an interactive educational system in order to achieve development in all its different elements and in all educational phases. The educational experts emphasize that the development process shall be comprehensive in order to include all educational system's elements at the same time.

Educational supervisory is considered one of the most important elements in the educational system. The execution of the educational policy requires an effective educational supervisory method which acts to improve it and to direct the human and financial resources toward that policy in addition to the best use of the policy and the participation in solving problems facing the execution of the educational policy as required. The educational supervisory bears the burden of directing the teachers and advising them during their work to face the global changes in scientific and technological knowledge and how to use such changes to serve the educational policy as well as achieving its goals (Khader, 2011).

The educational supervisory forms one of the most important processes which interacts with the rest of the educational process elements and it is considered as a link between the field and the supervising bodies; it is also considered as the technical arm for the Ministry of Education since it conveys its point of view as well as supplying the Ministry by the real and actual information about the positive points of the work and the areas of its developments: this will help the decision makers on the level of the Ministry and the field.

According to the aforementioned there is a need to keep this body in its best status in terms of development of skills, missions, supervisory roles in order to keep up with the changes in the educational process (Supervisory Guide, 2002). 


\subsection{Problem of the Study}

The purpose of this study is to answer the following two questions:

1 - What is the reality of the educational supervisors practices for supervisory activities from the point of view of the public school principals in Aqaba City - Jordan?

2- Are there any differences with statistical significance for the reality of the educational supervisors in conducting the supervisory activities from the point of view of the public schools principals in Aqaba city-Jordan which referred to the variables of (sex, qualifications, management experience years?.

\subsection{Study Objectives}

The study aims:

1- To identify the practices of the educational supervisors in conducting supervisory activities from the point of view of the public schools principals in Aqaba city - Jordan.

2- To identify the reality of the practices of the educational supervisors in conducting the supervisory activities in Aqaba city - Jordan according to the variables of (sex, qualifications and managerial experience) among the sample subjects.

3- To provide a number of recommendations and suggestions in the light of the study results.

\subsection{Importance of the Study}

The importance of this study is determined by the following:

1- It will provide a clear vision for the people in charge which may be applied and used in the field of educational supervision.

2- It may benefit the educational supervisors in Aqaba Educational Directorate through providing them by a feedback about their educational supervisory practices.

3- To encourage researchers to conduct more studies in the field of the educational supervisory.

\subsection{Definitions' of the Study}

The study definitions are defined as follow:

Educational Supervisor: is a university graduate supervisor whose mission is based on the academic specialty in curriculum and education, and he is the theoretical academic reference for the diploma student who is preparing his/her diploma in the of educational qualification and who stimulates the diploma student to evaluate his/her performance in the light of discovering the relation between theory and practice" (Al Dasoki,2009,13).

Educational Supervisor is defined operationally: as: a leader appointed by the Ministry of education to take over a group of technical and administrative missions to improve the learning and education processes.

Supervisory Activities: it is a group of procedural works conducted by the educational supervisor to improve the processes of learning and education through providing the help to the teachers to improve their professional growth as well as improving their performance level (Al Mogaied,2006). The researcher adopts this identification.

The Principal: is identified as "an educational leader who owns skills and specifications required by the roles to be practiced by him in managing the school to achieve its objectives in a safe and satisfying environment" (Abdo,2000,98)

The Principal defined operationally as: the person appointed by the Directorate of education and he is in charge of running the school and directing the staff as well as coordinating its activities in addition to providing the suitable educational environment in order to achieve the school vision and mission.

Aqaba City: Aqaba city is located in the Southern part of Jordan on the shores of the Red Sea and it is the center of Aqaba Governorate and it is about $330 \mathrm{KM}$ from Amman the capital city of Jordan. Its area is $375 \mathrm{Sq} \mathrm{Km}$ and its population about 188.000 . It is the fifth largest city in the kingdom. Its weather is desert weather and almost there is no rain during the year.

\subsection{Limitation of the Study}

This study was limited to principals(male \& female), who are working in public schools in Aqaba city - Jordan during the first semester if the school year( 2017/2018). 


\section{Reviewing the Relevant Theoretical Literature}

\subsection{Educational Supervision Concept}

The educators and researchers have not agreed on a specific definition for the educational supervision and this disagreement is referred to the difference in philosophies and points of views concerning the nature of the supervisory process and the mission of the educational supervisory which resulted in deferent definitions of the educational supervision. Tafesh(2004) defined the educational supervision as" a group of examined activities carried out by specialized educators to help the teachers to develop their selves as well as to improve their educational and evolutional practices inside and outside the class room and overcome all difficulties that may face them in executing the prescribed curriculum in addition to achieve the pre-planned educational objectives which all aim to create the desired changes in the students behaviors and their ways of thinking in order to enable them to build their societies and to defend their country.

In the light of the education and learning law and the national experience in the field of the educational supervision, the educational supervision is considered as an educational process which aims to provide specialized technical services to develop the learning process in order to emphasize the improvement of teaching through applying a group of the procedures and methods required to improve the educational process on the level of the school, the staff, students and to meet such needs,(Supervisory Guide, 2002).

\subsection{Educational Supervision Importance}

(Al Oran, 2010) clarified the importance of the educational supervision as follow:

1 - The people naturally need help and cooperation with others and from this point arise the need for the educational supervisor since he/she is an advisor and mentor.

2- Since a number of unqualified persons in teaching jobs require the presence of a planner and a trainer and this matter can be achieved through an educational supervisor.

3- The new teacher regardless of his personality, training and readiness remains in need for help and guidance and this is can be achieved by the educational supervisor.

4-The presence of old teachers who were not trained on the modern methods of teaching emphasize the need for the educational supervisor.

5- The teacher who is distinguished in his performance - sometimes - needs supervision particularly when applying new ideas.

\subsection{Educational Supervision Objectives}

Most of the researchers in the field of the educational supervision agreed that the general purpose of the supervision is: the improvement of learning and education process which serve the integrated development of the students from all aspects in order to enable them to become productive individuals and being able to adapt themselves with the society.

Murssi (2001) indicated that there are four comprehensive objectives for the educational supervision represented in the following:

- Improvement of the educational process through a professional leadership of the schools, principals and the teachers.

- Evaluation of the educational organizations and providing the constructive proposals to improve such organizations.

- Development of the professional growth of the teachers as well as improvement of their performance level and teaching methods.

- Working towards the guidance and best use of human and financial resources.

\section{Previous Relevant studies}

References was made to a number of previous Arab and Foreign studies dealt with the Reality of educational Supervisors' Practices

\subsection{Arabic Studies}

Al Mugaied (2006) conducted a study aimed to identify the supervisorspractices in UNRWA schools in Gaza in the light of the total quality and how to develop them, the researcher used the analytical descriptive methodology. The sample subjects consisted of all educational supervisors at UNRWA schools in Gaza (58) supervisor and (187) 
principal (Male \& Female). The study achieved a number of results most important of them is: the level of the supervisory practices was high and the study referred to the differences with statistical significance between the average mean of the supervisors and the principals in the level of the supervision levels of the supervisory practices for the benefit of the educational supervisors and it also indicated that there are no differences between the average mean of the supervisors and the principals concerning the supervisory practices level in terms of sex variable, qualification variable and years of experience.

Abo Samra (2007) aimed to identify the reality of the supervisory practices for the high schools principals in Hebrew Governorate from the point of view of the teachers; the study sample consisted of (288) teachers (male \& female); the study used the descriptive survey methodology. The study results indicated that the supervisory practices of the principals were high. The study also indicated that there are no differences with statistical significance between the averages of the study sample subjects concerning the principals supervisory practices in terms of sex, qualifications and specialty variables; at the same time the study indicated that there are differences with statistical significance between the averages of the study sample subjects concerning the principals supervisory practices in terms of the directorate variable for the benefit of South Hebrew Directorate and the teacher years of experience variable for the benefit of teachers with over 15 years of experience.

Ghada Mohammad (2009) conducted a study aimed to identify the supervisory practices for the educational supervisors and its relation to the attitudes of the higher basic phase towards the profession in the Governorate of Amman the capital and from their point of views. The study sample consisted of (373) teachers (Male \& Female). The study indicated that the level of supervisory practices of the educational supervisors from the point of view of the teachers of the high basic elementary phase were medium and it also indicated that the level of the attitudes of the higher basic phase teachers towards the profession in the Governorate of Amman the capital was medium from their point of view. The study also indicated the presence of a correlation relationship with a statistical significance between the supervisory practices of the educational supervisors and the attitudes of the higher basic phase teachers towards the profession.

Faraj (2011) conducted a study aiming to identify the degree of approval of the educational supervisor on the supervisory capabilities in Libya; the researcher used the survey descriptive methodology; the study sample consists of (48) people. The study achieved a number of results where most important of them is that visits to the class room were of medium importance; evaluation of the class room visit was of high importance and of medium application; whereas the highest areas deemed necessary by the teachers in their teaching practices during the supervisory class rooms visits were the areas of motivation, lesson planning and the lowest was the academic growth. The study also indicated that there were no differences with statistical significance referred to sex and number of supervisory visits variables.

\subsection{Foreign Studies}

Feher (2001) conducted a study aiming to analyze the role of the educational supervisors in public schools in the United States from $(1970-2000)$ and it also included the educational supervisory models available for the educational supervisors during this period. The study was applied on general models from the schools; the researcher used the historical research methods. The study indicated that a great change has taken place in relation to the educational supervisory thinking when the supervisors have taken the concept of the educational supervisory in a comprehensive way and less procedural method; the educational supervisors spent most of the time working as evaluators for the teachers in the class rooms. The study showed that the role of the educational supervisors was not changed during the past period and they became specialized in teaching curriculum.

The study of (Ovando \& Huckestein, 2003) aimed to clarify the visions of the central office supervisors about the supervisory practices and how they perform their roles in the model schools in the districts in addition to their participations to improve the students' academic development. The researchers used the survey descriptive method and they also used the method of content analysis; the study sample consisted of (59) supervisor from the model schools in the districts of Texas. They were (36) male and (23) female. The researchers prepared a questionnaire which included (12) dimension in addition to an open question to achieve the purpose of the study. The most important results of the study were: the educational supervisor should conduct four important missions: development of the teaching staff, planning of curriculum in addition to his/her role in providing the different teaching resources as well as his/her role as an important element in improving the students' performance through providing the help to the school and its teachers. The respondents illustrated four roles for the educational supervisor: facilitator, staff developer, curriculum planner and resources provider.

Elko (2005) conducted a study aimed to follow up the sustainability in improving the educational supervisory practices and the development of the self- professional guidance as well as the qualitative performance among the 
educational staff based in the school. Data were gathered through interviews and from the documents related to the educational policy. The study revealed a number of results where the most important is that the group subjected to the clinical supervision was most satisfied in the light of the assistance provided for them to guide their behavior more than the governing group and the study also indicated that the teachers were more satisfied by the clinical supervision more than the routine supervision.

\subsection{What Distinguishes this Study from the Previous Studies}

Through the review of the Arabic and foreign previous studies it has been noticed that the previous studies targeted the educational supervisory in different Arabic and foreign environments and conducted based on different variables such as (sex, qualifications, experience .....) and most of the researchers followed the survey descriptive methodology and the historical research such as Feher's study(2001) as well as interviews and review of documents such as Elko's study(2005), the present study took benefit from the previous studies in terms of:

- Building the theoretical frame work of the study.

- $\quad$ Formulation of the study problem and questions.

- Building and developing the study questionnaire.

- $\quad$ Specifying the study sample.

- Identification of the suitable procedures for the study

- Selection of the suitable statistical methods and techniques for the study.

The present study is distinguished by taking the previous studies in to consideration in terms of presentation and analysis of the previous studies related to the supervisors practices; this study will participate in enriching the scientific side since it discusses an important subject which is the reality of the educational supervisors practices in conducting the supervisory activities and it is also the first study of its kind in Aqaba city to the best knowledge of the researcher.

\section{Methodology}

This study followed the descriptive Survey approach at the most appropriate for this types of studies.

\subsection{Population and Sample of the Study}

The study sample consisted of all public schools principals (population) (Male \& Female) in Aqaba city a total of (22) principal.

\subsection{Study Instrument}

To achieve the study objectives the researcher developed a questionnaire to collect the data based on the literature review of the related studies; the researcher also gets the assistance from educational supervisors. The questionnaire consists of four domains and (46) paragraph. Table (1) below shows the study instruments domains:

Table 1. Study Instruments Domains

\begin{tabular}{ccc}
\hline No & Domain & Number of paragraphs \\
\hline 1 & School Administration & 12 \\
2 & Curriculum \& text books & 9 \\
3 & Teaching \& Learning & 17 \\
4 & Human relationships & 8 \\
5 & Over all Area & 46 \\
\hline
\end{tabular}

\subsection{Questionnaire Validity}

To verify validity of the study instrument the researcher presented the questionnaire to (11) of the teaching staff at the faculty of Education at the University of Jordan to insure the validity in items of construction, language, integrity and clarity. The remakes of all arbitrators were taken in to consideration.

\subsection{Questionnaire Reliability}

To ensure the firmness of the study instrument the researcher applied it on an anonymous sample out of the study sample area and the sample consists of (12) principal (Female \& Male) and through the test - retest method and then the Person correlation coefficient was calculated and reached (80.5). This result was considered suitable for the application of the study. 


\subsection{Statistical Processing Methods}

The fife degrees Liker's hierarchy was adopted to measure the reality of the educational supervisors conduct for educational activities in descending order as follow: (very high degree,high degree, medium, low degree, very small degree) and they were numerically represented $(1,2,3,4,5)$. The following scale was used to judge the arithmetic means:

$1-5=3 / 4=1.33$

\section{1-2.33 low evaluation degree}

2.34-3.66 Medium evaluation degree

\subsection{7-5 High evaluation degree}

\section{Study Results}

In this section, the researcher present the study results in a according with its questions at follows:

5.1 Results Related to Question: What is the Reality of the Educational Supervisors Practices for Supervisory Activities from the Point of View of the Public School Principals in Aqaba City - Jordan?

To answer this question the arithmetic means and the standard deviations for the reality of the educational supervisors practices in conducted the supervisory activities from the point of view of the schools principals in public schools in Aqaba - Jordan were exerted and the following table (2) shows the results.

Table 2. The arithmetic means and the standard deviations for each domain of the of the study in a descending order

\begin{tabular}{cccccc}
\hline Rank & No. & domain & Arithmetic mean & Standard deviation & Degree \\
\hline 1 & 4 & Human relationship & 4.11 & 0.728 & High \\
2 & 2 & Curriculum\& text book & 3.98 & 0.827 & High \\
3 & 3 & Learning \& teaching & 3.75 & 0.939 & High \\
4 & 1 & School administration & 3.52 & 0.860 & Medium \\
& & Total mean & $\mathbf{3 . 8 0}$ & $\mathbf{0 . 7 5 4}$ & High \\
\hline
\end{tabular}

The data in table (2) indicated that the total mean for the reality of the educational supervisors practices for the supervisory activities from the point of view of the public schools principals in Aqaba - Jordan was high, it was (3.80) whereas the arithmetic means for the secondary areas came between $(3.52-4.11)$. The (human relationship area) came in the first rank with the highest arithmetic mean of (4.11) and with a high degree followed by the (curriculum and the text books) with an arithmetic mean of (3.98) with a high degree and then the (Learning and teaching area) with an arithmetic mean of (3.75) with a high degree; the (school administration came in the last rank with lowest arithmetic mean of (3.52) and with a medium degree.

The following is a detailed presentation for the reality of the educational supervisors practices in public schools from the point of view of the schools' principals in Aqaba - Jordan and on the level of each area of the study domains (school administration, curriculum and the school books, teaching and learning, human relationships) and as follows:

\subsubsection{School Administration Domain}

Table 3. The arithmetic means and the standard deviations for the reality of educational supervisors' practices for the supervisory activities in the domain of school administration in a descending order in Aqaba city

\begin{tabular}{|c|c|c|c|c|c|}
\hline Rank & No. & Paragraphs & mean & S.d & Degree \\
\hline 1 & 9 & $\begin{array}{l}\text { The supervisor identifies the school efficiency in achieving its } \\
\text { objectives in accordance with clear standards. }\end{array}$ & 3.95 & .899 & High \\
\hline 2 & 10 & The supervisor participates in evaluating the school performance. & 3.82 & .853 & High \\
\hline 3 & 1 & The supervisor participates in preparing the development plan. & 3.73 & .1 .162 & High \\
\hline 4 & 6 & $\begin{array}{l}\text { The supervisor assists the school in solving problems that the } \\
\text { school may face. }\end{array}$ & 3.73 & 1.162 & High \\
\hline 5 & 7 & The supervisor follows up the school activities. & 3.59 & 1.221 & Medium \\
\hline 6 & 12 & $\begin{array}{l}\text { The supervisor participates in providing the suitable educational } \\
\text { environment for the teachers. }\end{array}$ & 3.59 & 1.008 & Medium \\
\hline 7 & 2 & $\begin{array}{l}\text { The supervisor executes projects that assist the improvement of the } \\
\text { students' performance. }\end{array}$ & 3.55 & 1.299 & Medium \\
\hline
\end{tabular}




$\begin{array}{llllll}8 & 8 & \begin{array}{l}\text { The supervisor works on the development of the school } \\ \text { environment. }\end{array} & 3.50 & 1.012 & \text { Medium } \\ 9 & 11 & \begin{array}{l}\text { The supervisor cooperates with the principal to develop the } \\ \text { achievement tests. }\end{array} & 3.36 & 1.255 & \text { Medium } \\ 10 & 3 & \begin{array}{l}\text { The supervisor identifies the educational needs for the school. } \\ \text { The supervisor assist the school to obtain all required needs and }\end{array} & 3.32 & 1.086 & \text { Medium } \\ 11 & 5 & \begin{array}{l}\text { tools. } \\ \text { The supervisor carries out local programs on the school level. } \\ \text { Total mean }\end{array} & \begin{array}{l}2.86 \\ \mathbf{3 . 5 4}\end{array} & \begin{array}{l}1.125 \\ \mathbf{0 . 8 6 0}\end{array} & \text { Medium } \\ \text { Medium }\end{array}$

The table (3) indicated that the arithmetic means vary between $(2.86-3.95)$ with a medium and high degree; the school administration domain has a medium degree with an arithmetic mean of (3.54); the paragraph ( the supervisor identifies the school efficiency in achieving its objectives in accordance with clear standards) came in the first rank with the highest arithmetic mean of (3.95) with a high degree whereas the paragraph( the supervisor carries out programs on the school level) came in the last rank with the lowest arithmetic mean of (2.86) and with a medium degree.

\subsubsection{The Curriculum and the Text Books Domain}

Table 4. The arithmetic means and the standard deviation for the reality of the educational supervisors practices in conducting the supervisory activities in Aqaba city for the curriculum and text books domain.

\begin{tabular}{|c|c|c|c|c|c|}
\hline Rank & No. & Paragraphs & mean & S,t & Degree \\
\hline 1 & 21 & $\begin{array}{l}\text { The supervisor directs the teacher to use the teacher guidance book } \\
\text { to apply the curriculum. }\end{array}$ & 4.27 & .935 & High \\
\hline 2 & 13 & The supervisor clarifies the objectives and contents for the teachers. & 4.18 & .958 & High \\
\hline 3 & 16 & $\begin{array}{l}\text { The supervisor guides the teachers to exploit all available capabilities } \\
\text { to enrich the curriculum. }\end{array}$ & 4.14 & .834 & High \\
\hline 4 & 15 & $\begin{array}{l}\text { The supervisor clarifies the importance of using teaching means and } \\
\text { the appropriate technologies. }\end{array}$ & 4.09 & .1 .065 & High \\
\hline 5 & 20 & $\begin{array}{l}\text { The supervisor helps the teacher to overcome the problems facing } \\
\text { the curriculum. }\end{array}$ & 4.09 & .811 & High \\
\hline 6 & 19 & $\begin{array}{l}\text { The supervisor assists the teacher to connect the curriculum with the } \\
\text { real life. }\end{array}$ & 3.95 & .950 & High \\
\hline 7 & 18 & $\begin{array}{l}\text { The supervisor directs the teacher to get benefit from the local } \\
\text { environment to enrich the curriculum. }\end{array}$ & 3.82 & .853 & High \\
\hline 8 & 17 & $\begin{array}{l}\text { The supervisor helps the teacher to apply the extracurricular which } \\
\text { support the curriculum. }\end{array}$ & 3.77 & 1.020 & High \\
\hline 9 & 14 & $\begin{array}{l}\text { The supervisor assists the teachers to analyze the text book. } \\
\text { Total mean }\end{array}$ & $\begin{array}{l}3.55 \\
3.98\end{array}$ & $\begin{array}{l}1.335 \\
\mathbf{0 . 8 3 7}\end{array}$ & $\begin{array}{l}\text { High } \\
\text { High }\end{array}$ \\
\hline
\end{tabular}

The (4) indicated that the arithmetic means varied from (3.55 - 4.27); the curriculum and text books came in a high degree with an arithmetic mean of (3.98). The paragraph (the supervisor directs the teacher to use the teacher's guide to effectively apply the curriculum) came in the highest rank with an arithmetic mean of (4.27) and with a high degree; whereas the paragraph (the supervisor assists the teachers to analyze the content of the text book) came in the last rank with the lowest arithmetic mean of (3.55) and with a low degree.

\subsubsection{Learning and Teaching Domain}

Table 5. Arithmetic means and standard deviations for the reality of the educational supervisors' practices in conducting the educational activities in Aqaba city in the area of learning and teaching in a descending order

\begin{tabular}{llllll}
\hline Rank & No. & Paragraph & mean & S.t & Degree \\
\hline 1 & 22 & $\begin{array}{l}\text { The supervisor guides the teacher to employ the teaching modern } \\
\text { strategies. }\end{array}$ & 4.41 & .734 & High \\
2 & 34 & $\begin{array}{l}\text { The supervisor appreciates the distinguished efforts of the teachers' } \\
\text { performance. }\end{array}$ & 4.18 & 1.006 & High \\
3 & 25 & $\begin{array}{l}\text { The supervisor follows up the progress of the curriculum in } \\
4.09\end{array}$ & 1.192 & High
\end{tabular}


accordance with annual plan by the teacher.

\begin{tabular}{|c|c|c|c|c|c|}
\hline 4 & 28 & The supervisor directs the teacher to improve the class environment. & 4.05 & ,844 & High \\
\hline 5 & 31 & $\begin{array}{l}\text { The supervisor encourages the teachers to exchange visits and } \\
\text { experiences. }\end{array}$ & 3.91 & 1.192 & High \\
\hline 6 & 37 & $\begin{array}{l}\text { The supervisor provides the teacher by proposals to improve } \\
\text { learning and teaching process. }\end{array}$ & 3.91 & 1.065 & High \\
\hline 7 & 27 & $\begin{array}{l}\text { The supervisor participates in developing the teacher's teaching } \\
\text { techniques. }\end{array}$ & 3.82 & 1.259 & High \\
\hline 8 & 24 & $\begin{array}{l}\text { The supervisor provides a direct assistance to the teacher to develop } \\
\text { his/her practices and performance. }\end{array}$ & 3.77 & 1.270 & High \\
\hline 9 & 35 & $\begin{array}{l}\text { The supervisor evaluates the teacher according to his/ her } \\
\text { achievement of the curriculum objectives. }\end{array}$ & 3.77 & .869 & High \\
\hline 10 & 26 & $\begin{array}{l}\text { The supervisor assists the teacher in the daily and the quarterly } \\
\text { planning. }\end{array}$ & 3.68 & 1.460 & High \\
\hline 11 & 29 & $\begin{array}{l}\text { The supervisor assists the teacher in providing references, books and } \\
\text { teaching leaflets. }\end{array}$ & 3.64 & 1.002 & High \\
\hline 12 & 30 & $\begin{array}{l}\text { The supervisor cooperates with the teacher in solving the problems } \\
\text { he/she may encounters. }\end{array}$ & 3.59 & .854 & Medium \\
\hline 13 & 23 & The supervisor participates in giving a number of applied lessons. & 3.55 & 1.335 & Medium \\
\hline 14 & 38 & $\begin{array}{l}\text { The supervisor organizes training courses and workshops to develop } \\
\text { the teachers' skills. }\end{array}$ & 3.55 & 1.299 & Medium \\
\hline 15 & 36 & $\begin{array}{l}\text { The supervisor evaluates the teaching process through the study of } \\
\text { the monthly and quarterly results. }\end{array}$ & 3.41 & 1.182 & Medium \\
\hline 16 & 32 & $\begin{array}{l}\text { The supervisor assists the teacher in preparing the examinations } \\
\text { according to the table of specifications. }\end{array}$ & 3.32 & 1.460 & Medium \\
\hline \multirow[t]{2}{*}{17} & \multirow[t]{2}{*}{33} & $\begin{array}{l}\text { The supervisor follows up the analysis of the monthly and quarterly } \\
\text { examinations results }\end{array}$ & 3.05 & 1.290 & \multirow[t]{2}{*}{ Medium } \\
\hline & & Total mean & 3.75 & 0.939 & \\
\hline
\end{tabular}

The table (5) indicated that the arithmetic means varied from (3.05 - 4.41) and between medium and high degree; the learning and teaching domain came in a high degree with an arithmetic mean of (3.75)... the paragraph (the supervisor guides the teacher to employ the teaching modern strategies) came in the first rank with the highest arithmetic mean of (4.41) whereas the paragraph ( the supervisor follows up the results of the monthly and quarterly examinations ) came in the last rank and with the lowest arithmetic mean of (3.05) and a medium degree.

\subsubsection{The Human Relationships Domain}

Table 6. The arithmetic means and standards deviations for the reality of the educational supervisors practices in conducting their supervisory activities in Aqaba city for the area of human relationships in a descending order

\begin{tabular}{|c|c|c|c|c|c|}
\hline Rank & No. & Paragraph & Mean & S.t & Degree \\
\hline 1 & 39 & The supervisor builds a human relationships with the school. & 4.50 & .673 & High \\
\hline 2 & 40 & $\begin{array}{l}\text { The supervisor encourages the principals and the teachers to create } \\
\text { positive interaction. }\end{array}$ & 4.50 & .598 & High \\
\hline 3 & 45 & The supervisor works with the staff in a team spirit. & 4.23 & .813 & High \\
\hline 4 & 43 & $\begin{array}{l}\text { The supervisor builds human relations with the principals and the } \\
\text { teachers. }\end{array}$ & 4.18 & .958 & High \\
\hline 5 & 41 & $\begin{array}{l}\text { The supervisor keens on developing human relations with local } \\
\text { community. }\end{array}$ & 4.05 & 1.046 & High \\
\hline 6 & & $\begin{array}{l}\text { The supervisor keens on building positive relations between the } \\
\text { teachers. }\end{array}$ & 4.05 & 1.133 & High \\
\hline 7 & 46 & $\begin{array}{l}\text { The supervisor assists the school to open its doors to the local } \\
\text { community. }\end{array}$ & 3.91 & 1.019 & High \\
\hline 8 & 42 & The supervisor builds positive relations with the students. & 3.86 & 1.082 & High \\
\hline 9 & 47 & $\begin{array}{l}\text { The supervisor assists the school to cooperate with the local } \\
\text { community. }\end{array}$ & 3.73 & 1.077 & High \\
\hline
\end{tabular}


The table (6) indicated that the arithmetic means varied from $(3.73-4.50)$ and with a high degree; the human relationships came in a high degree with an arithmetic mean of (4.11); the two paragraphs ( the supervisor builds human relations with the school and the supervisor encourages the principals and the teachers to create a positive interaction) came in the first rank and with the highest mean of (4.50) and with a high degree, whereas the paragraph ( the supervisor assists the school to cooperate with the local community ) came in the last rank and the lowest arithmetic mean of $(3,73)$ and in a high degree.

\subsection{Results Related to the Second Question}

Are there any differences with statistical significance for the reality of the educational supervisors in conducting the supervisory activities from the point of view of the public schools principals in Aqaba city-Jordan which referred to the variables of (sex, qualifications, management experience years?.

To answer this question the arithmetic means and the standard deviations and the " $T$ " test for the independence samples were extracted from the point of view of the public schools principals in Aqaba city about the reality of the educational supervisors practices for the educational activities which may be referred to (sex, qualification, management experience years); the following results were obtained:

\subsubsection{Sex}

Table 7. The arithmetic means and the standard deviations and the " $T$ " test for the independence samples from the point of view of the public schools principals in Aqaba city for the reality of the educational supervisors in conducting the educational activities which are referred to sex variable:

\begin{tabular}{|c|c|c|c|c|c|c|c|}
\hline domain & Sex & No. & $\begin{array}{l}\text { Arithmetic } \\
\text { mean }\end{array}$ & $\begin{array}{l}\text { Standard } \\
\text { Deviation }\end{array}$ & $\begin{array}{l}\text { "T" } \\
\text { value }\end{array}$ & $\begin{array}{l}\text { Freedom } \\
\text { degrees }\end{array}$ & $\begin{array}{l}\text { Statistical } \\
\text { Significance }\end{array}$ \\
\hline School & Male & 10 & 3.63 & .974 & & & \\
\hline administration & Fem. & 12 & 3.42 & .973 & .560 & 20 & 2.582 \\
\hline Text book and & Male & 10 & 3.88 & .943 & & & \\
\hline curriculum & Fem. & 12 & 4.07 & .747 & -.545 & 20 & .592 \\
\hline Learning \& & Male & 10 & 3.64 & 1.141 & & & \\
\hline Teaching & Fem. & 12 & 3.83 & .775 & -.469 & 20 & .644 \\
\hline Human & Male & 10 & 3.94 & .817 & -.979 & 20 & .339 \\
\hline Relations & Fem. & 12 & 4.25 & .648 & & & \\
\hline \multirow{2}{*}{ Total mean } & Male & 10 & 3.74 & .931 & & & \\
\hline & .Fem & 12 & 3.85 & .609 & -.340 & 20 & .738 \\
\hline
\end{tabular}

Table (7) indicated that the "T" value, for the point of view of the public schools principals in Aqaba city about the reality of the educational supervisors' practices in conducting the supervision activities which may be referred to sex variable, has reached the total degree of the scale (0.340) and this value is statistically insignificance at the level of $(0.05)$. The " $\mathrm{T}$ " value for the school administration area reached $(0.560)$ and for the curriculum and text book was(-0.545); for learning and teaching(-0.469); for the human relationships(-0.979) and they are all statistically insignificance values at the level of 0.55 and this indicates that there are no differences in the public schools principals' point of views about the reality of the educational supervisors practices in conducting the supervisory activities according to sex variable and for all other secondary areas of the scale.

\subsubsection{The scientific Qualification}

Table 8. The arithmetic means and the standard deviations and the " $T$ " test for the independence samples from the point of view of the public schools principals in Aqaba city for the reality of the educational supervisors in conducting the educational activities which are referred to sex the scientific qualification:

\begin{tabular}{|c|c|c|c|c|c|c|c|}
\hline domain & Qual. & No. & $\begin{array}{l}\text { Arithmetic } \\
\text { mean }\end{array}$ & $\begin{array}{l}\text { Standard } \\
\text { Deviation }\end{array}$ & $\begin{array}{l}\text { "T" } \\
\text { value }\end{array}$ & $\begin{array}{l}\text { Freedom } \\
\text { degrees }\end{array}$ & $\begin{array}{l}\text { Statistical } \\
\text { Significance }\end{array}$ \\
\hline School & B.A & 17 & 3.52 & .933 & & & \\
\hline administration & M.A. & 5 & 3.52 & .630 & .007 & 20 & 995 \\
\hline
\end{tabular}




\begin{tabular}{llllllll} 
Text book and & B.A & 17 & 3.93 & .881 & & & \\
curriculum area & .M.A & 5 & 4.16 & .660 & -.516 & 20 & .612 \\
Learning \& & B.A & 17 & 3.68 & 1.051 & & & \\
Teaching area & .M.A & 5 & 3.98 & .359 & -.615 & 20 & .546 \\
Human & B.A & 17 & 4.07 & .793 & -.457 & 20 & .653 \\
relations area & M.A & 5 & 4.24 & .487 & & & \\
Total mean & B.A & $\mathbf{1 7}$ & $\mathbf{3 . 7 6}$ & $\mathbf{. 8 4 3}$ & $\mathbf{- . 4 6 7}$ & $\mathbf{2 0}$ & $\mathbf{. 6 4 6}$ \\
& M.A & $\mathbf{5}$ & $\mathbf{3 . 9 4}$ & $\mathbf{. 3 3 7}$ & & & \\
\hline
\end{tabular}

Table (8) indicated that the "T" value, for the point of view of the public schools principals in Aqaba city about the reality of the educational supervisors practices in conducting the supervision activities which may be referred to the qualification variable, has reached the total degree of the scale $(-0.467)$ and this value is statistically insignificance at the level of (0.05). The " $\mathrm{T}$ " value for the school administration area reached $(0.007)$; for the curriculum and text book was(-0.516) ; for learning and teaching $(-0.615)$; for the human relationships $(-0.415)$ and they are all statistically insignificance values at the level of 0.05 and this indicates that there are no differences in the public schools principals' point of views about the reality of the educational supervisors practices in conducting the supervisory activities according to the qualification variable and for all other secondary areas of the scale, in Aqaba city - Jordan.

Table 9. The arithmetic means and the standard deviations and the "T" test for the independent samples from the point of view of the public schools principals in Aqaba city for the reality of the educational supervisors in conducting the educational activities which are referred to the years of experience:

\begin{tabular}{|c|c|c|c|c|c|c|c|}
\hline domain & $\begin{array}{l}\text { experience } \\
\text { Years }\end{array}$ & No. & $\begin{array}{l}\text { Arithmetic } \\
\text { mean }\end{array}$ & $\begin{array}{l}\text { Standard } \\
\text { Deviation }\end{array}$ & $\begin{array}{l}\text { "T" } \\
\text { value }\end{array}$ & $\begin{array}{l}\text { Freedom } \\
\text { degrees }\end{array}$ & $\begin{array}{l}\text { Statistical } \\
\text { Significance }\end{array}$ \\
\hline \multirow{2}{*}{$\begin{array}{l}\text { School } \\
\text { administration }\end{array}$} & $\begin{array}{lll}\text { Less } & \text { than } & 7 \\
\text { years } & & \end{array}$ & 11 & 3.58 & .962 & \multirow[b]{2}{*}{.344} & \multirow[b]{2}{*}{20} & \multirow[b]{2}{*}{.735} \\
\hline & $\begin{array}{l}7 \text { years and } \\
\text { more }\end{array}$ & 11 & 3.45 & .786 & & & \\
\hline \multirow{2}{*}{$\begin{array}{l}\text { Text book and } \\
\text { curriculum }\end{array}$} & $\begin{array}{l}\text { Less than } \\
\text { years }\end{array}$ & 11 & 3.93 & .889 & \multirow[b]{2}{*}{-.308} & \multirow[b]{2}{*}{20} & \multirow[b]{2}{*}{.761} \\
\hline & $\begin{array}{l}7 \text { years and } \\
\text { more }\end{array}$ & 11 & 4.04 & .799 & & & \\
\hline \multirow{2}{*}{$\begin{array}{l}\text { Learning } \\
\text { Teaching }\end{array}$} & $\begin{array}{l}\text { Less than } 7 \\
\text { years }\end{array}$ & 11 & 3.74 & .964 & \multirow[b]{2}{*}{-.039} & \multirow[b]{2}{*}{20} & \multirow[b]{2}{*}{.969} \\
\hline & $\begin{array}{l}7 \text { years and } \\
\text { more }\end{array}$ & 11 & 3.75 & .961 & & & \\
\hline \multirow{2}{*}{$\begin{array}{l}\text { Human } \\
\text { relations area }\end{array}$} & $\begin{array}{l}\text { Less than } 7 \\
\text { years }\end{array}$ & 11 & 4.11 & .674 & \multirow{2}{*}{-.000} & \multirow{2}{*}{20} & \multirow{2}{*}{.1 .000} \\
\hline & $\begin{array}{l}\text { More than } 7 \\
\text { years }\end{array}$ & 11 & 4.11 & .812 & & & \\
\hline Total mean & & $\begin{array}{l}11 \\
11\end{array}$ & $\begin{array}{l}3.81 \\
3.80\end{array}$ & $\begin{array}{l}.793 \\
.752\end{array}$ & -.018 & 20 & .986 \\
\hline
\end{tabular}

Table (9) indicated that the "T" value, for the point of view of the public schools principals in Aqaba city about the reality of the educational supervisors practices in conducting the supervision activities which may be referred to the areas of experience variable, has reached the total degree of the scale (-0.018) and this value is statistically insignificance at the level of (0.05). The "T" value for the school administration area reached $(0.344)$ and for the curriculum and text book was(-0.308) and for learning and teaching(-0.039) and for the human relationships(0.000 ) and they are all statistically insignificance values at the level of 0.05 and this indicates that there are no differences in the public schools principals' point of views about the reality of the educational supervisors practices in conducting the supervisory activities according to the years of experience variable and for all other secondary areas of the scale in Aqaba city - Jordan.

\section{Discussion of Results}

\subsection{Discussion of the Results Related to the First Question}


The paragraphs varied between high and medium degree and the overall mean for the reality of the educational supervisors' practices in conducting the supervisory activities in public schools in Aqaba - Jordan was in a high degree of (3.85) and this is referred to the knowledge of the educational supervisors of the roles and missions delegated to them, this result is in conformity with Al Mugaied study(2006) whereas it was with a medium degree in Ghada Mohammad Study(2009).

\subsection{Discussion of the Results Related to the Second Question}

The results indicated that there are no differences with statistical significance in the answers of the study sample which may be referred to (sex, qualification and managerial experience variables), the researcher attributed that to the practices of the educational supervisors for the same activities in all schools that they visit and this result is in conformity with the result of (Al Mugaed.2006) study and (Abo Samra,2007) study.

\section{Recommendations}

Within the frame work of the content of this study in shedding the light on the educational supervisors' practices in Aqaba - Jordan the researcher proposes the following recommendations:

1- There should be more cooperation between the supervisor and the school principal to upgrade the school level.

2- To grant the educational supervisor a sufficient time in the area of the relation with local community and to conduct local activities on the level of the school.

3- To conduct similar studies in other areas in Jordan and to compare the results with the results of this study.

\section{References}

\section{Arabic References}

Abdo, A. (2005). Elementary School Management. Cairo: Al nahdah Bookshop.

Abo Samra, M. A., Al Asaili, R., \& Abo Helaiel, F. (2007). The reality of the high school principals practices in Hebrew Governorate from the teachers' point of view. Al-Khalil research Journal, 3(1), 161-188.

Aldasouki, I. (2009). The modern trends in practical physical education and its development techniques. Faculty of Physical Education, Quna, Egypt.

Almugaied, A. (2006). The reality of the educational supervisors practices at UNRWA in Gaza in the light of the total quality principles and methods of its development. Unpublished M.A.thesis, Islamic University, Gaza, Palestine.

Aloran, I. (2010). The Educational supervision and its problems. Amman: Yafa scientific house for publication \& distribution.

Elko, L. (2005). Supervision Practices Promoting continuous self-directe Professional Growth and Quality Performance among Educational Personnel in the School context, M.A Thesis in University of Alberta. Dissertation.

Faraj, F. (2011). Evaluation of the educational supervisors performance in Aljabal Al akhder division in the light of their scientific qualifications. unpublished M.A. thesis, Omar Almukhtar University, Lybia.

Feher, S. (2001). The Role of Educational Supervision in United States Public Schools from 1970 to 2000 Reflected in the supervision Literature, Doctor Thesis in Pennsylvania State University. Dissertation abstract.

\section{Foreign References}

Khader, R. (2001) Modern Educational Supervision: Basics and Concepts. Amman: Ghaida'a house for publication and distribution.

Ministry of Education. (2002). Educational supervision Guide. Amman: Directorate of Training, rehabilitation and educational Supervision.

Mohammad, G. (2013). The supervisory practices of the educational supervisors and its relation with the teachers of the higher basic elementary phase in the capital city of Amman from their point of view. M. A. thesis, Middle East University, Amman, Jordan.

Murssi, M. (2011). Teaching Administration and its principles and applications. Cairo, the books world.

Ovando, M. N., \& Huckestein, M. L. (2003). Perceptions of the role of the Central Office Supervisors in Exemplary Texas school districts. Paper presented to the American Educational Research Association Annual Conference, Chicago. 
Tafess, M. (2004). Creativity in Educational Supervision and School Management. Amman, Alforgan House.

\section{Copyrights}

Copyright for this article is retained by the author(s), with first publication rights granted to the journal.

This is an open-access article distributed under the terms and conditions of the Creative Commons Attribution license (http://creativecommons.org/licenses/by/4.0/). 